ZBigniew ZioŁo

Uniwersytet Pedagogiczny, Kraków

\title{
Miejsce innowacyjności w kształtowaniu procesów rozwoju gospodarczego układów przestrzennych
}

W warunkach nasilających się procesów globalizacji coraz bardziej zmieniają się relacje konkurencyjne między podmiotami gospodarczymi, sektorami, krajami, czy grupami państw. Dążą one do pogłębiania istniejących i opanowywania nowych rynków dla oferowanych przez siebie produktów, usług i kapitału. W podnoszeniu pozycji konkurencyjnej szczególne znaczenie odgrywa dostarczanie coraz bardziej innowacyjnych produktów i usług, które zwykle odznaczają się nowymi zastosowaniami, wyższą jakością i relatywnie niższą ceną. Sprostanie tym wyzwaniom wymaga przygotowania przedsiębiorczej i innowacyjnej kadry pracowniczej, kapitału inwestycyjnego, sprzyjającego klimatu otoczenia instytucjonalnego, społecznego i kulturowego dla wdrażania rozwiązań innowacyjnych. Podstawową rolę w tym zakresie odgrywa jakość i poziom edukacji, możliwości rozwijania działalności produkcyjnej, usługowej oraz wdrażania nowoczesnych rozwiązań organizacyjnych.

Ta szczególnie aktualna problematyka badawcza podejmowana była w wielu studiach dotyczących roli nauki w: rozwoju gospodarczym (Kukliński 1995), kształtowaniu nowoczesnego biznesu (Carnicky, Krupa, Skotny 2011), kształtowaniu kreatywnych przemysłów i układów metropolitalnych (Klasik 2008, Stryjakiewicz 2011, Męczyński 2010, Stryjakiewicz, Kaczmarek, Męczyński, Parysek, Stachowiak 2010, Stryjakiewicz, Stachowiak 2010), czy rozwoju kapitału społecznego (Heffner, Kamińska 2010).

S. Ciok i H. Dobrowolska-Kaniewska (2009, s. 10) podejmując zagadnienie polityki innowacyjnej państwa i jej wpływu na potencjał innowacyjny Dolnego Śląska przedstawili szereg cech i określeń innowacji przyjmowanych przez wielu autorów, m.in.: J.A. Schumpetera (który traktuje innowacyjność jako wprowadzanie nowych produktów, nowych metod produkcji, znalezienie nowych rynków, zdobycie nowych źródeł surowców oraz wprowadzenie nowej organizacji), P.F. Druckera (specyficzne narzędzia przedsiębiorczości, które nadają zasobom nowe możliwości tworzenia dóbr), P. Kotlera (produkcja dobra, które postrzegane jest przez kogoś jako nowe), R.W. Griffina (kierowany wysiłek organizacji na rzecz opanowania nowych produktów i usług, bądź też nowych zastosowań istniejących produktów i usług; innowacja jest również formą kontroli w tym sensie, że pomaga organizacji dotrzymać kroku konkurencyjności), W. Marczyka (wartość kulturowa materialna, np. narzędzia, lub niematerialna, np. metoda pracy, która w danych warunkach czasowych i przestrzennych 
jest traktowana przez ludzi jako nowa), A. Kuklińskiego (zdolność do tworzenia i absorbowania innowacji; kompleks zjawisk i procesów tworzących nowe wzorce technologii produkcji), O. Manuala (wprowadzenie do praktyki w przedsiębiorstwie nowego lub znacząco ulepszonego rozwiązania w odniesieniu do: produktu (towaru, usługi), procesu, marketingu lub organizacji; istotą innowacyjności jest wdrożenie nowości do praktyki; wdrożenie nowego procesu, nowych metod marketingowych lub nowej organizacji; definicja ta przyjęta została w Programie Operacyjnym Innowacyjna Gospodarka). Autorzy przyjmują, że innowacje mogą dotyczyć różnych dziedzin i wyróżniają innowację: produktową (udoskonalanie wyrobu już wytwarzanego lub rozszerzanie struktury asortymentowej o nowe produkty), procesową (zmienianie metod wytwarzania, poprzez zastosowanie nowej lub ulepszonej technologii), organizacyjną (wprowadzanie nowych metod organizacji, czy zmian strategii działania) i marketingową (wprowadzanie zmian wyglądu produktu, opakowań itp.).

Różnorodne podejścia do analizy kształtowania procesów innowacji zaznaczyły się w Pracach Komisji Geografii Przemysłu (Zioło, Rachwał 2008, 2009a, 2009b, 2010a, 2010b, 2011), poświęconych: problematyce badawczej geografii przemysłu, wpływu globalizacji i integracji europejskiej na transformację struktur przemysłowych, funkcji przemysłu w kształtowaniu społeczeństwa informacyjnego, procesów transformacji przemysłu i usług w regionalnych i krajowych układach przestrzennych oraz w wybranych krajach, wpływu kryzysu na zachowania przedsiębiorstw i struktur regionalnych.

Procesy innowacyjne uaktywnia odpowiednio przygotowany człowiek funkcjonujący w określonych warunkach otoczenia: instytucji edukacyjnych, atrakcyjności obszaru dla aktywizacji czynników wzrostu, zwłaszcza jego kulturalnej innowacyjności, inwestycyjnego kapitału krajowego i zagranicznego, jakości organów władzy państwowej i władz samorządowych a także jakości instrumentów pośredniego i bezpośredniego oddziaływania, otoczenia finansowego oraz jakości polityki społeczno-gospodarczej (Zioło 2012)1.

Wychodząc z powyższych przesłanek w niniejszych rozważaniach podjęta zostanie problematyka roli innowacyjności w kształtowaniu firm i procesów rozwoju gospodarczego, społecznego i kulturowego. Zmierzać będziemy do określenia zarysu kształtowania procesów innowacji, roli wybranych czynników w pobudzaniu innowacyjności oraz przedstawienia miejsca Polski w strukturze rangowej pod względem zaawansowania procesów innowacyjności. Wstępnie zakładamy, że szeroko rozumiana innowacyjność jest podstawowym czynnikiem pobudzania wzrostu ekonomicznego oraz podnoszenia jakości i poziomu życia. Wyrazem tego jest historyczny proces kształtowania bazy ekonomicznej, odznaczający się zmianami rozwoju społeczno-gospodarczego, od fazy feudalnej poprzez fazę industrialną i postindustrialną po fazę społeczeństwa informacyjnego.

Zakładamy, że w przemianach tych podstawową rolę odgrywają procesy innowacyjne, które w podstawowym stopniu wpływają na rozwój cywilizacyjny. Przejawiają się one

${ }^{1}$ Za E. Kwiatkowskim (1989, s. 41) można przyjąć, że „ostatecznym źródłem wydarzeń historycznych, tak samo jak faktów ekonomicznych, postępu i rozwoju cywilizacyjnego są ludzie. Dlatego też, chcąc badać głębiej wszystkie pozycje polityczno-gospodarcze państwa polskiego, jego aktywa i pasywa należy rozpocząć od człowieka, od jego wartości dynamicznej i historycznej w stosunku do państwa”. Na tym tle można ocenić także jakość wybranych w drodze demokratycznych wyborów przedstawicieli władzy ustawodawczej, którzy w głównym stopniu powinni podejmować zagadnienia związane z podnoszeniem innowacyjności i konkurencyjności gospodarki, i społeczno-kulturowej przestrzeni krajowej, a nie koncentrować swoją uwagę na doraźnych, często nieistotnych i populistycznych sprawach, które nie wymagają odpowiedniego przygotowania merytorycznego i wiedzy. 
w szerokim zakresie i wpływają na zmiany zachowań ludzi, przedsiębiorstw, instytucji, metod gospodarowania, postaw społecznych, kulturowych oraz wpływają na zmiany układów światowych, europejskich, krajowych, regionalnych i prowadzą do wykształcania się nowych relacji funkcjonalnych zachodzących między ich elementami strukturalnymi. Procesy te mogą być w odpowiedni sposób stymulowane przez odpowiednie decyzje zarządów przedsiębiorstw (korporacji), władz państwowych i samorządowych, a także mogą być wspierane przez organizacje społeczne i pozarządowe. Dlatego ważnym problemem pozostaje dążenie do coraz precyzyjniejszego poznania procesu kreowania nowoczesnej działalności przedsiębiorstwa i jej wpływu na innowacyjność gospodarki. Poznawanie związanych z nimi reguł pozwala na podejmowanie określonych działań sterujących procesami innowacyjnymi w przedsiębiorstwach, instytucjach, czy układach przestrzennych.

\section{PrZESŁANKI KSZTAŁTOWANIA PROCESU INNOWACYJNEGO}

Szczególne przyspieszenie procesów innowacyjnych nastąpiło $\mathrm{w}$ fazie industrializacji, w której bazą ekonomicznego i społecznego rozwoju stała się działalność przemysłowa. Dzięki pracom naukowo-badawczym i wdrażaniu nowych rozwiązań technologicznych, technicznych i organizacyjnych, znacznemu zintensyfikowaniu ulegał proces doskonalenia metod produkcji oraz zwiększania ich efektywności poprzez stopniowe wdrażanie mechanizacji a następnie automatyzacji i robotyzacji produkcji. Proces ten wymuszał także wdrażanie nowych metod organizacji i zarządzania kapitałem i zasobami pracy. Wdrażany postęp eliminował z produkcji człowieka, czego odzwierciedleniem było stopniowe zmniejszanie się liczby zatrudnionych w przemyśle oraz spadek ich udziału w aktywizacji rynków pracy. Wraz ze zwiększaniem efektywności produkcji następowały zmiany społeczne przejawiające się w konieczności podnoszenia poziomu wykształcenia, zmianach struktury zawodów i specjalności pracowniczych, a także kierunków kształcenia oraz rozwoju miast i urbanizacji obszarów wiejskiego otoczenia ${ }^{2}$.

Współcześnie w nasilających się warunkach konkurencyjności, rozwój działalności gospodarczej wymusza wprowadzanie innowacyjnych rozwiązań nie tylko w procesach technologicznych i technicznych oraz usługach, ale także w strukturach społecznych, kulturze i polityce gospodarczej. Zmieniają się bowiem reguły wytwarzania i podziału dóbr materialnych i niematerialnych, a także alokacja efektów działalności gospodarczej. Dzięki temu zwiększa się i modernizuje potencjał produkcyjny oraz następuje systematyczne pomnażanie kapitału, który zapewnia wysoką dynamikę rozwoju gospodarczego, społecznego i kulturowego. Prowadzi to do zwiększania efektywności pracy, która tworzy przesłanki do kreowania nowej bazy ekonomicznej i rozwoju społeczeństwa informacyjnego. Towarzyszy temu nasilający się proces koncentracji kapitału, liberalizacja wymiany międzynarodowej w zakresie przepływów finansowych i kapitałowych oraz wzrost i umiędzynarodowianie znaczenia nauki i prac badawczych. Stopniowo doprowadzały one do ograniczania znacze-

${ }^{2}$ Kształtowanie się tych procesów było przedmiotem badań zespołowych pracowników byłej Katedry Geografii Ekonomicznej pod kierunkiem prof. dr Marii Dobrowolskiej ujętych m.in. w syntetycznych opracowaniach dotyczących wzajemnych relacji procesów industrializacji i urbanizacji np. na obszarze Tarnobrzeskiego Okręgu Przemysłowego i Górnego Śląska (Rajman 1969, Dobrowolska 1968, Zioło 1978, Długosz, Zioło 2010). 
nia rynków regionalnych i krajowych oraz wykształcania się rynku globalnego. Powiązania w zakresie produkcji przemysłowej, rozwoju handlu, obniżania ceł oraz liberalizacja międzynarodowych przepływów doprowadziły do rozwijania współpracy, która wpłynęła na kształtowanie się różnych wspólnot gospodarczych, w tym Unii Europejskiej.

W wyniku nasilających się procesów rozwoju cywilizacyjnego kraje rozwinięte wkraczają w nową fazę kształtowania społeczeństwa informacyjnego ${ }^{3}$. Podstawową cechą tego społeczeństwa jest: wysoko rozwinięty sektor usług, przede wszystkim sektor usług nowoczesnych (bankowość, finanse, telekomunikacja, informatyka, badania i rozwój oraz zarządzanie), wysoki poziom kształcenia społeczeństwa, renesans społeczności lokalnej, urozmaicanie życia społecznego, znaczniejsze wykorzystywanie automatyzacji i robotyzacji w procesach produkcji, technicznych narzędzi komunikacji oraz magazynowania i przetwarzania informacji. Pojęciem tym określa się także społeczeństwo, w którym towarem staje się informacja traktowana jako szczególne dobro niematerialne, niekiedy cenniejsze od dóbr materialnych.

Nasilające się w przestrzeni światowej powiązania w zakresie: produkcji, więzi kooperacyjnych, surowcowych, kapitałowo-finansowych, organizacyjnych, usługowych, kadrowych i in., prowadzą do kształtowania się społeczeństwa globalnego. Stanowi ono sprzężony systemem wszystkich struktur gospodarczych, społecznych, różnego rodzaju instytucji i procesów występujących w zbiorowości poszczególnych państw czy narodów. Podkreśla to konieczność coraz precyzyjniejszego poznawania złożonych procesów innowacyjnego rozwoju jako podstawy podejmowania decyzji w zakresie kształtowania podmiotów gospodarczych oraz wytyczania strategicznych kierunków rozwoju gospodarczego, społecznego i kulturowego różnej skali układów przestrzennych.

\section{ZARYS KSZTALTOWANIA PROCESU INNOWACYJNEGO}

Podstawową rolę w kształtowaniu procesów innowacyjności odgrywają działania mające na celu unowocześnienie funkcjonowania firm oraz instytucji otoczenia biznesu, które wpływają na podnoszenie jakości życia i poziomu rozwoju gospodarczego i kulturowego społeczeństwa. Pobudzanie i nasilanie tych procesów w zasadniczym stopniu zależy od podejmowanych decyzji zarządów przedsiębiorstw, określonej polityki gospodarczej państwa, sprawności władz rządowych i samorządowych oraz instytucji otoczenia biznesu. Przesłanki działań innowacyjnych wynikają głównie z chęci maksymalizacji zysku danej firmy w warunkach nasilającej się konkurencji.

Wdrażanie rozwiązań innowacyjnych do działalności firm i gospodarki dokonuje się w drodze kolejnych etapów, które w nawiązaniu do strategicznych kryteriów wyboru dzia-

\footnotetext{
${ }^{3}$ Początkowo pojęciem tym określano społeczeństwo, w którym towarem staje się informacja traktowana jako szczególne dobro niematerialne, równoważne lub cenniejsze nawet od dóbr materialnych. Pojęcie to zostało wprowadzone w 1963 roku przez Japończyka T. Umesao w artykule o teorii ewolucji społeczeństwa opartego na technologiach informatycznych, a spopularyzowane przez K. Koyama w 1968 roku w pracy „Wprowadzenie do teorii informacji”. W nawiązaniu do przedstawionych idei w Japonii powstał „Plan utworzenia społeczeństwa informacyjnego, jako cel narodowy na rok 2000”. Zawierał on strategię zakładającą rozwój informatyzacji, która umożliwi przyśpieszenie rozwoju intelektualnego społeczeństwa oraz zintensyfikowanie tworzenia wiedzy, a w mniejszym stopniu zwraca uwagę na dalsze uprzemysławianie kraju.
} 
łalności przedsiębiorstwa, obejmują: badania podstawowe, prace laboratoryjne, produkcję w skali półtechnicznej (doświadczalnej) oraz rynkową masową kierowaną na rynek (ryc. 1).

Szczególne znaczenie w kształtowaniu procesów innowacji mają badania podstawowe, które odkrywają nowe idee, poszerzają naszą wiedzę dotyczącą otaczającego nas świata, pozwalają zrozumieć jego złożone struktury oraz ich proces przemian pod wpływem zmieniających się czynników i wskazują określone kierunki podejmowania prac naukowych. Służą one budowaniu koncepcji teoretycznych, celem możliwości wytwarzania nowych produktów, czy podejmowania bardziej efektywnej działalności usługowej. Weryfikacja idei i związanych z nimi koncepcji jest podstawą programowania odpowiednich działań i projektowania rozwiązań technologicznych dla nowych lub doskonalenia wytwarzanych już produktów (Zioło 2009b). Wyniki tych badań stanowią podstawę dla podejmowania prac nad nowymi metodami produkcji, które wdrażane do działalności gospodarczej będą przyczyniać się do podnoszenia konkurencyjności firm i w konsekwencji przyczyniać się będą do podnoszenia ich pozycji na rynku oraz zwiększania zysków. W pracach tych przyjmuje się zasadę, że innowacyjność to nie tylko gromadzenie informacji, przechowywanie jej oraz rozwijanie idei, ale głównie umiejętność w zakresie wykorzystania ich, poprzez wdrożenie do produkcji czy działalności usługowej, celem podnoszenia efektywności ekonomiczno-technicznej działalności przedsiębiorstwa.

Badania podstawowe mogą być prowadzone w jednostkach naukowych występujących w strukturze danej korporacji, podejmowane w drodze zamówień w ośrodkach akademickich lub innych wyspecjalizowanych ośrodkach naukowo-badawczych. W rozwoju korporacji kluczowe znaczenie ma zarząd, gdzie zapadają decyzje dotyczące wytyczania strategicznych celów rozwoju działalności gospodarczej, w tym podejmowania badań podstawowych i prac badawczo-rozwojowych oraz określania wielkości nakładów inwestycyjnych przeznaczonych na poszczególne etapy wdrażania nowego produktu ${ }^{4}$. Wiążą się one także z ograniczaniem ryzyka, które związane jest z pracami badawczymi i wdrożeniowymi. Dla zarządu mogą być także interesujące nowe osiągnięcia badawcze ośrodków naukowych nie związanych z daną korporacją, które już zostały osiągnięte ale jeszcze nie wdrożone do działalności produkcyjnej w innych korporacjach. Dlatego ważną rolę w tym zakresie odgrywa także śledzenie i analizowanie prac ośrodków naukowych występujących w przestrzeni światowej, które mogą być przydatne dla rozwijania działalności danej korporacji ${ }^{5}$. W oparciu o przyjęte założenia strategii rozwoju oraz rachunek ekonomicznej efektywności działalności produkcyjnej czy usługowej, określa się potencjalne możliwości pogłębiania istniejących i pozyskiwania nowych rynków. Na tej podstawie dokonuje się także często wyboru nowych, najkorzystniejszych miejsc lokalizacji działalności produkcyjnej czy usługowej, które najczęściej związane są z liberalniejszymi nakazami ekologicznymi, istniejącą już infrastrukturą techniczną oraz tańszymi i odpowiednio przygotowanymi zasobami pracy. Na tym etapie

${ }^{4} \mathrm{~W}$ odniesieniu do uwarunkowań krajowych problematykę tę podjął P. Śleszyński (2007, 2010), analizując gospodarcze funkcje kontrolne zarządów przedsiębiorstw działających w krajowej przestrzeni gospodarczej.

${ }^{5} \mathrm{~Np}$. korporacja Boeinga przy pracy nad nowym dreamlinerem skorzystała z porad inżynierów pracujących w ponad 100 innych korporacjach na całym świecie, podobnie AGD producent sprzętu domowego, chcąc obniżyć koszty przeznaczane na badania i rozwój ogłasza konkursy i wykorzystuje najlepsze projekty zgłaszane przez absolwentów i studentów. W jednym z konkursów wzięło udział ponad 3500 uczestników z 88 krajów - gdyby korporacja chciała samodzielnie stworzyć taką liczbę projektów, musiałaby przez wiele lat przeznaczyć wielomiliardowe wydatki na ten cel. 


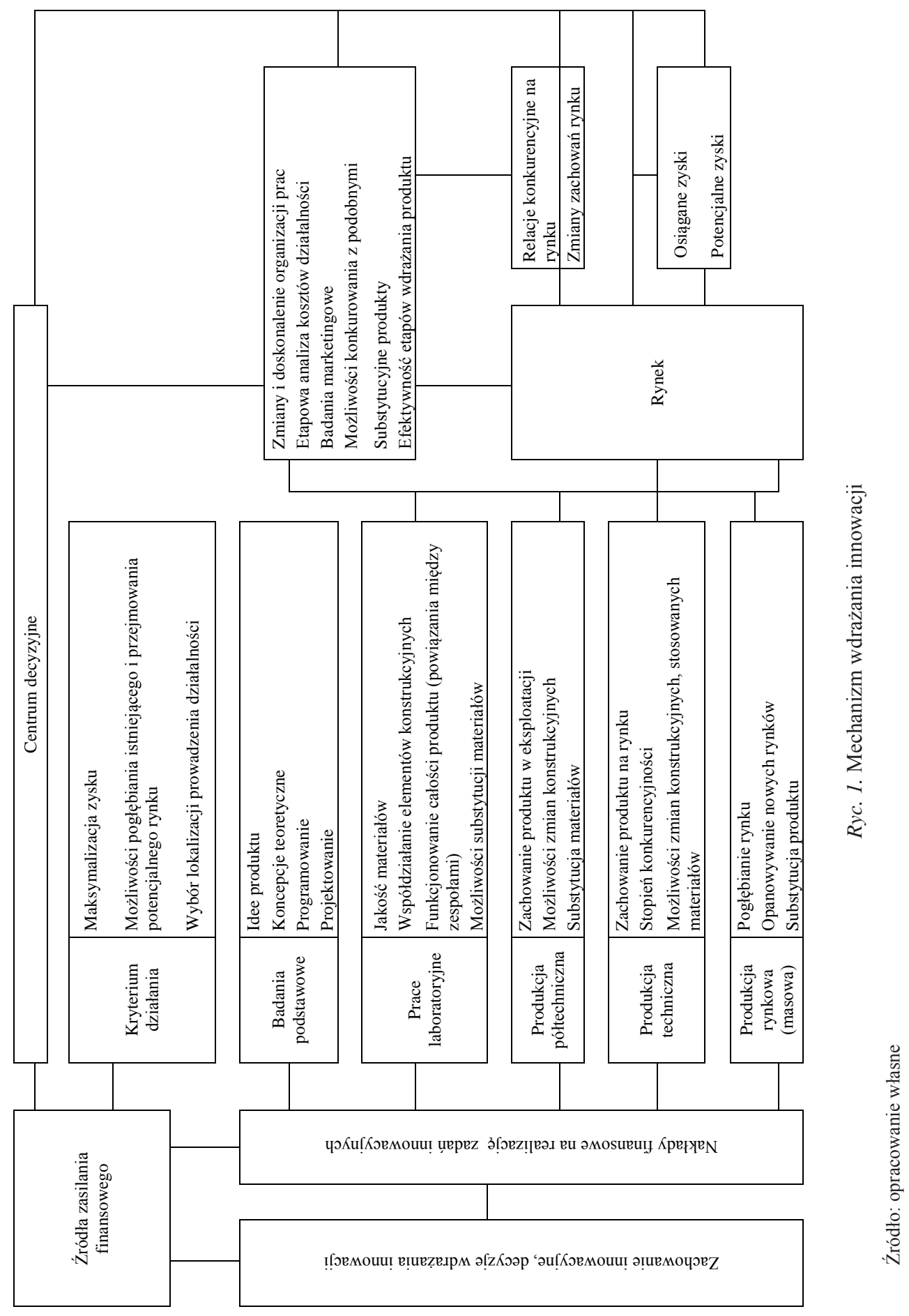


szczególnie ważne znaczenie ma identyfikacja potencjalnych innowacyjnych produktów, zarządzanie bazą różnorodnych koncepcji i pomysłów, a także tworzenie nowych koncepcji dla realizacji przyjętych idei oraz ocena i wdrażanie najkorzystniejszych rozwiązań. Szybka identyfikacja nowych tendencji rozwoju jest szczególnie ważna dla przedsiębiorstw, ponieważ umożliwia ona korygowanie realizowanych strategii rozwoju produkcji oraz działania na rzecz zdobywania przewagi konkurencyjnej (np. konkurencja w zakresie upowszechnienia nowej przeglądarki między Microsoft a Google).

Kolejnym etapem są prace laboratoryjne. Mają one na celu opracowanie konstrukcyjne nowego lub doskonalenie dotychczasowego produktu, wybór nowych materiałów o odpowiednich właściwościach technicznych, opracowanie nowych elementów i podzespołów, które mogą być zastosowane w nowym lub modernizowanym produkcie. Celem podniesienia wartości użytkowej produktu, czy tendencji do obniżania jego kosztu wytwarzania, poszukuje się także możliwości zastosowania substytucyjnych materiałów, wykorzystania już produkowanych podzespołów oraz możliwości nawiązania współpracy z innymi firmami ${ }^{6}$. Osiągnięte na tym etapie wyniki badawcze stanowią istotny element rozwijania nowej produkcji i są ważnym ogniwem procesu innowacyjności. W pracach nad nowymi produktami zwraca się także uwagę na stwarzanie korzystnego klimatu dla podejmowania nowoczesnej produkcji oraz rozwijania innowacyjnej przedsiębiorczości. Dokonuje się tego często w powiązaniu z instytucjami międzynarodowymi a także rządami poszczególnych krajów ${ }^{7}$.

Celem prac w skali półtechnicznej jest wytworzenie pierwszych, doświadczalnych egzemplarzy wyrobów a następnie ich testowanie pod kątem zachowania w eksploatacji. Zdobyte w tym zakresie wyniki wskazują na potrzebę wprowadzenia ewentualnych zmian konstrukcyjnych, zmian doboru zastosowanych podzespołów, elementów, czy materiałów, dla podniesienia ich własności technicznych i ekonomicznych w fazie eksploatacji ${ }^{8}$.

Końcowym etapem jest produkcja masowa kierowana na konkurencyjny rynek. Ważną rolę odgrywa tu stały monitoring dotyczący jakości zachowania produktu w procesie eksploatacji, możliwości pogłębiania istniejących i opanowywania nowych rynków, a także zachowań konkurentów i możliwości wykorzystania produktu jako bardziej konkurencyjnego substytutu w stosunku do podobnych wyrobów.

${ }^{6}$ Producenci samolotów w Europie mieli do wyboru dwa typy silników: Rolls-Royce Trent 900, który wybrały linie Singapore Airlines, Lufthansa, lub produkowany przez General Electric i Pratt\&Whitney, który wybrały Air France i Emirates (D. Wasilewska, „Kłopoty superjumbo”, Rzeczpospolita, 6 listopada 2010).

${ }^{7}$ Korporacja EADS i siedem krajów NATO (Belgia, Francja, Hiszpania, Luksemburg, Niemcy, Turcja, Wielka Brytania) osiągnęły porozumienie finansowe dotyczące wspólnego podjęcia produkcji wojskowego samolotu transportowego A400M. Planuje się, że seryjna produkcja samolotu zostanie podjęta w zakładach Airbus Military w San Pablo koło Sewilli, w trzecim ośrodku lotniczym po Tuluzie i Hamburgu. Planuje się, że wspomniane kraje zakupią 170-180 samolotów, przy czym koszt jednej maszyny będzie wynosił ok. 120 mln dol. (P. Rudzki, „Porozumienie finansowe w sprawie A400M”, Rzeczpospolita, 7 listopada 2010).

${ }^{8}$ Opóźnienie dostaw największego pasażerskiego samolotu Airbus A380, związane było z silnikami, które wraz z maksymalnymi osiągami technicznymi ulegały awarii. Spowodowało to dodatkowe koszty, które wyniosły 5 mln dol. Będący już w eksploatacji samolot Qantasa także miał kłopoty z silnikiem Rolls-Royce, co jak się sądzi wynikało z niedopatrzenia w projekcie napędu (D. Walewska „Kłopoty superjumbo”, Rzeczpospolita, 6 listopada 2010). Koncern Toyota skierował do stacji serwisowych ponad 300 tys. samochodów dla usunięcia wad w układzie hamulcowym (P. Rudzki, „Toyota: Hamulce do naprawy”, Rzeczpospolita, 8 lutego 2010). Podobnie koncern Volkswagen ze względu na wadliwe smarowanie tylnych kół w samochodzie produkowanym w Brazylii, skierował do serwisów blisko 200 tys. pojazdów. 
Wady konstrukcyjne, czy błędy w montażu produktów wymagają od koncernów dużych nakładów finansowych. Stąd między poszczególnymi etapami przygotowania produktu do wejścia na rynek występuje ciągły przepływ informacji mających na celu stworzenie wyrobu o najlepszych parametrach technicznych, ekonomicznych i użytkowych, który równocześnie będzie coraz bardziej konkurencyjny na rynku9

Podstawowe znaczenie w zakresie organizacji i finansowania poszczególnych etapów prac ma centrum decyzyjne (zarząd przedsiębiorstwa), które określa całościową strategię rozwoju działalności przedsiębiorstwa, zarządza własnymi zasobami finansowymi i kapitałowymi, nawiązuje współpracę z zewnętrznymi źródłami zasilania finansowego (bankami centralnymi, komercyjnymi wyspecjalizowanymi w kredytowaniu odpowiedniej działalności gospodarczej) i in. W oparciu o przyjęte kryteria określone na podstawie rachunku ekonomicznego podejmowane są odpowiednie decyzje, które dotyczą: wytwarzania nowych produktów, kontynuowania dotychczasowej produkcji, wdrażania zmian technologicznych lub przenoszenia finalnej produkcji, lub podzespołów do fabryk zlokalizowanych na terenie innych krajów. W zależności od stopnia zaawansowania technologicznego i jakości kadr pracowniczych oraz możliwości obniżania kosztów przenoszona jest niekiedy na tereny innych krajów cała produkcja danego wyrobu (Zioło 2009b) ${ }^{10}$.

Produkcja masowa kierowana na rynek umożliwia osiąganie określonych efektów ekonomicznych, które przyczyniają się do zasilania źródeł finansowania przedsiębiorstwa. Osiągnięte wyniki dają podstawę do oceny efektywności podejmowanych decyzji i stanowią ważne przesłanki dla dalszego zarządzania strategicznego przez zarząd firmy.

\section{KSZTAŁTOWANIE PROCESÓW INNOWACJI W STRUKTURZE GOSPODARKI NARODOWEJ}

Procesy wdrażania innowacji w strukturze gospodarki narodowej przebiegają z różnym nasileniem a podstawową rolę w tym zakresie odgrywa struktura własności podmiotów gospodarczych, ich potencjał ekonomiczny oraz udział w rynku. Wzrost innowacyjności gospodarki wymaga niekiedy znacznych nakładów finansowo-kapitałowych, które mogą pochodzić z zasobów finansowych przedsiębiorstw, kredytów lub z budżetu państwa. Podstawową rolę w tym zakresie spełniają zarządy poszczególnych przedsiębiorstw, które w oparciu o realizowane cele strategiczne, w głównym stopniu wpływają na nasilanie wdra-

${ }^{9}$ Korporacja Locheed Martin przygotowała 15 gotowych do testów myśliwców piątej generacji F-35 Lighting II, który był najdroższym projektem w historii światowych zbrojeń a jego koszty wzrosły do 385 mld dol. i przewiduje się, że jeden samolot będzie kosztował $156 \mathrm{mln}$ dol. W trakcie testów okazało się m.in., że spadochrony pod katapultującymi fotelami zostały złożone w odwrotną stronę, a w wersji przeznaczonej do lądowania na lotniskowcach nie działa hak, który zahacza linę hamulcową. Projekt współfinansują: Wielka Brytania, Norwegia, Dania, Holandia, Włochy, Turcja, Australia i Kanada. Przeciąga to wprowadzenie jednostki do służby, podczas gdy chińczycy także już testują samolot piątej generacji J-20.

${ }^{10}$ Koło Poznania w Antoninku produkowany jest VW Caddy, jeden z typów samochodów dostawczych. W wyniku nakładów inwestycyjnych ponad 1 mld euro w zakładzie pracuje ponad 6 tys. pracowników a jego zdolności produkcyjne sięgają 150 tys. samochodów. W fabryce jest odlewnia i spawalnia. Znaczna część dostaw pochodzi z polskich fabryk - blacha pochodzi z Wrześni, silniki z Polkowic, szyby i siedzenia z Sandomierza, nadto zakład kooperuje z 50 innymi dostawcami z Polski, w tym z 18 położonymi na terenie województwa wielkopolskiego (J. Szalek, „VW Caddy made in Poland”, Gazeta Wyborcza, 12 lutego 2010). 
żania innowacji do produkcji, zarządzania, działań marketingowych, doskonalenia kadr i in. Dlatego ważną rolę odgrywają miejsca lokalizacji centrów decyzyjnych, które mogą mieć swoje siedziby na terenie kraju lub na terenie innych państw (ryc. 2).

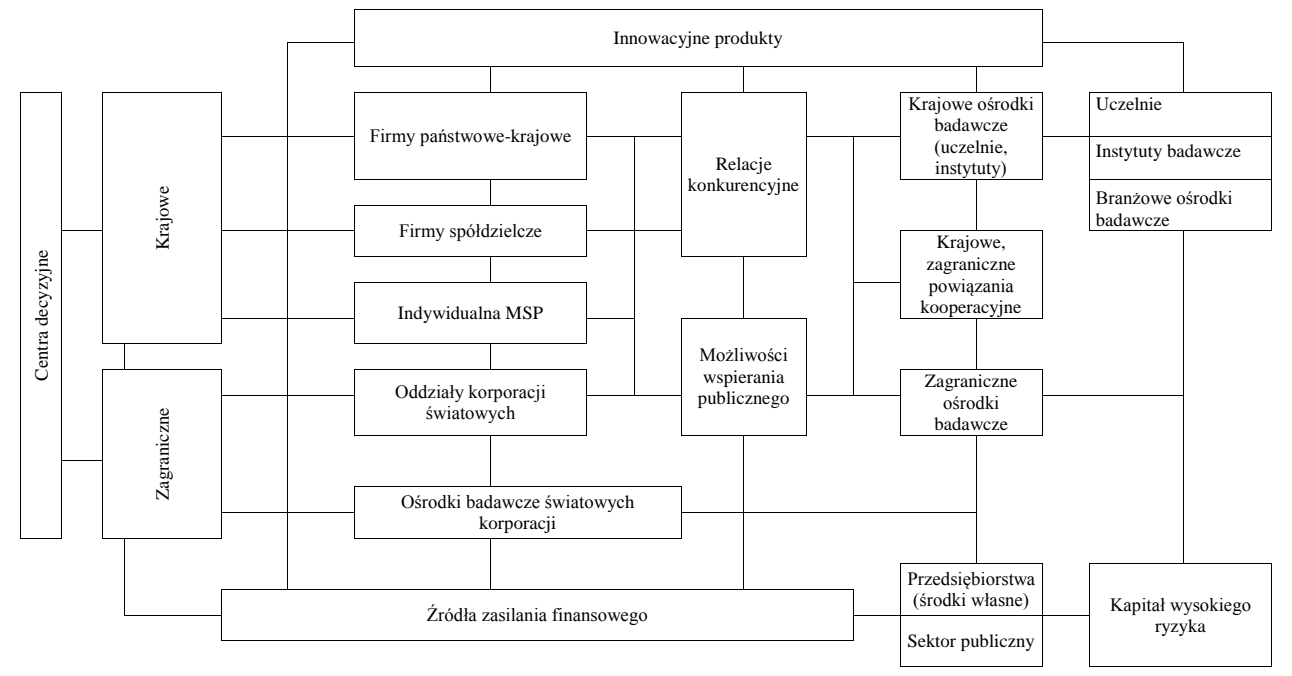

Ryc. 2. Miejsce innowacji w strukturze firm i gospodarki narodowej

Źródło: opracowanie własne

Na terenie kraju zlokalizowane są ośrodki decyzyjne zarządzające przedsiębiorstwami będącymi własnością: państwa, różnych form spółdzielczych i kapitału prywatnego. Reprezentują one podmioty gospodarcze o różnym potencjale ekonomicznym, przedsiębiorstwa duże, średnie, małe lub mikro przedsiębiorstwa. Krajowe prywatne przedsiębiorstwa odznaczają się zwykle mniejszym potencjałem ekonomicznym. Funkcjonują one w wyniku powiązań produkcyjnych np. w zakresie kooperacji z firmami zagranicznymi, czy krajowymi lub oferują gotowe produkty kierowane bezpośrednio na rynek wewnętrzny lub zagraniczny.

Przedsiębiorstwa krajowe współpracujące z zagranicznymi korporacjami są zwykle wyposażone w urządzenia pochodzące z zagranicznych firm wraz z odpowiednimi systemami organizacyjnymi. Wytwarzają one produkty w oparciu o dostarczane dokumentacje technologiczne, często także surowce i materiały do produkcji. Przedsiębiorstwa te w zasadniczym stopniu wykorzystują więc zagraniczną myśl naukowo-badawczą i techniczną oraz powiązania w zakresie zaopatrzenia w części zamienne, czy wykonywanie remontów urządzeń produkcyjnych. Dlatego również nie stwarzają one większego zapotrzebowania na produkty krajowych rozwiązań ośrodków naukowo-badawczych czy akademickich.

Przedsiębiorstwa krajowe pracujące na potrzeby rynku (zagranicznego, krajowego) również w znacznym stopniu wyposażają się w maszyny i urządzenia importowane z zagranicy, co również pociąga za sobą powiązania zagraniczne w zakresie zaopatrzenia w części zamienne. W konsekwencji przedsiębiorstwa te nie stwarzają rynku i nie zgłaszają ofert prac naukowo-badawczych do krajowych ośrodków naukowych i naukowo-badawczych. Stanowi to poważną barierę w zakresie pozyskiwania środków na prace badawczo-rozwojowe ze źródeł pozarządowych. 
Grupa krajowych małych i średnich przedsiębiorstw zwykle wykorzystuje starszy park maszynowy, oferuje głównie mniej technologicznie zaawansowane produkty oraz dysponuje stosunkowo niskimi zasobami kapitału aby go przeznaczać na prace naukowo-badawcze. Wynika to także z małej stabilności instrumentów prawnych, możliwości udzielania kredytów, wysokości obciążeń finansowych, a także mało stabilnej sytuacji gospodarczej i politycznej, które wpływają na brak możliwości budowania dłuższych strategii rozwojowych, wymagających podejmowania innowacyjnych działań inwestycyjnych. Również sytuacja rynku krajowego często nie stwarza zachęty dla wprowadzania nowych rozwiązań technologicznych i technicznych. Tradycyjne produkty znajdujące popyt na miejscowym rynku wykorzystują dawne urządzenia produkcyjne, które nie uległy jeszcze całkowitej eksploatacji.

Relacje konkurencyjne na rynku wymuszają także na przedsiębiorstwach krajowych dążenie do ciągłego doskonalenia istniejących lub wprowadzania na rynek nowych produktów. Procesy modernizacyjne dokonują się zwykle poprzez zakup nowych technologii, które wymagają bardziej nowoczesnych maszyn i urządzeń. Dostarczane są one zwykle przez zagraniczne korporacje, które wiążą je później ze sobą poprzez dostarczanie części zamiennych, surowców, półfabrykatów, nowych rozwiązań technicznych czy przejmowanie zasad organizacji i zarządzania itp. Zachętą do takich działań są często korzystne umowy kredytowe na działania modernizacyjne w oparciu o zagraniczne rozwiązania technologiczne i techniczne. Nasilają się w ten sposób uzależnienia danego przedsiębiorstwa od zagranicznych korporacji, czy źródeł finansowania, które umożliwiają podejmowanie nowszej i bardziej konkurencyjnej produkcji. Zagraniczne korporacje nie udostępniają jednak najnowszych rozwiązań technologicznych tak długo, aż nie wprowadzą u siebie bardziej nowoczesnych. Dopiero po ich wprowadzeniu chętnie dzielą się starszymi rozwiązaniami, które w odniesieniu do sytuacji krajowych są uważane za nowoczesne ${ }^{11}$.

Krajowe przedsiębiorstwa, głównie w wyniku ich powiązań biznesowych zlecają także często wykonanie prac badawczych ośrodkom zagranicznym. Umożliwia to zakup po niższych cenach maszyn i urządzeń oraz dokumentacji pozwalających na wprowadzanie nowszych technologii produkcyjnych czy usługowych.

W przestrzeni krajowej pojawiają się firmy wykorzystujące nowoczesne rozwiązania własnych prac naukowo-badawczych, ale ze względu na brak dostępu do kapitału wysokiego ryzyka nie są w stanie rozwinąć produkcji na większą skalę ${ }^{12}$. Stąd przejmowane są one

${ }^{11}$ Krajowe firmy mają rekordowe środki finansowe zgromadzone na bankowych kontach - w latach 20072011 wzrosły one ze 125 mld zł do 193 mld zł. Tym też urząd uzasadnił podwyżkę składki rentowej płaconej przez przedsiębiorstwa od lutego 2012 r. o 2 pkt procentowe. Obecnie są one częściowo wykorzystywane na skup akcji, np. największa firma informatyczna Asseco Poland przeznaczyła na ten cel $450 \mathrm{mln}$ zł, IDM SA - $109 \mathrm{mln}$, Boryszew - $100 \mathrm{mln}$, IC Corp - 30 mln zł. Zgromadzone środki wynikają z obaw, jak głęboki będzie kryzys i jak mocno odczują to przedsiębiorstwa. Gdyby udało się przełamać inwestycyjne bariery, skierowanie gotówki na działalność gospodarczą byłoby najlepszym programem stymulacji gospodarki. Podobnie ,gdyby korporacje amerykańskie uruchomiły swoje rezerwy szacowane na 2 bln dol. i przeznaczyły je na inwestycje to przyćmiłyby wszystkie wcześniejsze rządowe programy. Jeżeli zmniejszy się stopień niepewności, przedsiębiorstwa same w większym stopniu będą je wykorzystywać podejmując działalność inwestycyjną (I. Sudak, „Polskie firmy mają rekordowe 183 mld zł na kontach", Gazeta Wyborcza, 21 grudnia 2011).

${ }^{12}$ Przykładem tego jest firma Ammono R. Dwilińskiego, która w zakresie nowych odkryć pokonała światowych gigantów i rewolucjonizuje rynek półprzewodników. Losy jej świadczą, że nawet najlepsze pomysły i przedsięwzięcia skazane są na upadek lub przejęcie przez kapitał zagraniczny. Dysponowała ona najlepszą w świecie technologią produkcji azotku galu, uruchomiono produkcję na którą było 10-krotnie większe zapotrzebowanie przez światowe firmy. Ze względu na wadliwy system wspierania innowacyjnych produktów, wynikający wła- 
zwykle przez kapitał międzynarodowy, który dysponując odpowiednimi środkami, rozwija produkcję na skalę rynku światowego osiągając znaczące korzyści ekonomiczne.

Coraz częściej pojawiają się nowe przedsiębiorstwa, które podejmują nowoczesną produkcję w oparciu o własne rozwiązania konstrukcyjne i technologiczne i stopniowo opanowują zarówno rynki krajowe jak i międzynarodowe ${ }^{13}$.

W przestrzeni krajowej funkcjonują także oddziały produkcyjne, usługowe, badawczo -rozwojowe i in., które są elementami światowych korporacji, mającymi swoje centra decyzyjne na terenie innych państw. Powstają one zwykle w formie bezpośrednich inwestycji zagranicznych lub są efektem prywatyzacji i przejęcia przez kapitał zagraniczny, który zwykle odznacza się dużym potencjałem ekonomicznym ${ }^{14}$. Podejmowane przez zarządy decyzje nawiązują głównie do celów strategicznych korporacji ale także reagują na kierunki działania polityki danego kraju, gdzie mają swoje siedziby ${ }^{15}$.

Korporacje zagraniczne mające swoje oddziały produkcyjne czy usługowe na terenie danego kraju z reguły wykorzystują rozwiązania technologiczne, techniczne, organizacyjne i monitoringowe wypracowane przez własne ośrodki badawcze występujące w strukturze danej korporacji, osiągnięcia innych wyspecjalizowanych zagranicznych ośrodków badawczych, czy akademickich. Nowe rozwiązania wypracowane przez te jednostki przenoszone są jako innowacyjne do oddziałów zlokalizowanych na terenie innego kraju ${ }^{16}$. Dotyczą one dokumentacji nowych rozwiązań technologicznych w zakresie modernizacji technicznej wytwarzanych produktów, zmian parku maszynowego i struktur organizacyjnych procesów produkcyjnych, wielkości zasilania kapitałowego i finansowego, alokacji zysków, metod utrzymania istniejących i poszukiwania nowych rynków, powiązań kooperacyjnych $\mathrm{i}$ in. W warunkach naszego kraju duże przedsiębiorstwa przemysłowe w znacznym stopniu powiązane są z kapitałem zagranicznym i wykonują najczęściej prace montażowe lub pro-

ściwie z braku polityki innowacyjnej, firma nie miała szans na otrzymanie kredytu (chodziło o 10 mln euro) na rozwój produkcji i w konsekwencji została przejęta przez kapitał. Jest to wynik kompletnej ignorancji czynników rządowych, które, należy wnosić, nie mają chęci lub przygotowania w zakresie rozwijania innowacyjnych rozwiązań i kreowania firm rozwijających nowoczesną produkcję na terenie kraju (A. Włodarski, „Hieny w Dolinie Śmierci", Gazeta Wyborcza, 7-8 stycznia 2012).

${ }^{13}$ Dobrym przykładem jest firma AZO Digital z Gdańska, która opracowała technologię i produkcję nowego elektronicznego zapalnika, wykorzystywanego do oświetlenia. Młodzi absolwenci Politechniki Gdańskiej opanowali nową technologię, z którą nie mogły sobie poradzić światowe korporacje, m.in. Osram i Philips. Należy nadmienić, że pierwsze elektroniczne zapalniki zostały wykorzystane we wschodnim Londynie a nie w Polsce, co pośrednio wskazuje na niski stopień zainteresowania innowacyjnymi rozwiązaniami technologicznymi w kraju (A. Kiełbasiński, „Firma z Gdańska, która zawstydziła oświetleniowców z całego świata”, Gazeta Wyborcza, 9 czerwca 2011).

${ }^{14}$ W 2010 r. w skali światowej pierwszą pozycję pod względem sprzedaży zajmuje Wal-Mart Stores, której wartość sprzedaży wynosi 421,8 mld dol., drugą Royal Dutch Shell - 369,1 mld dol., siódmą Toyota Motor - 202,6 mld a jedenastą Volkswagen Group - 168,3 mld, podczas gdy krajowa wartość PKB wynosiła w tym czasie 469,3 mld dol.

${ }^{15}$ Przykładem tego może być np. przeniesienie produkcji Pandy z Polski na teren Włoch, utrata pewnych przywilejów francuskich fabryk samochodów jeżeli przeniosą swoją produkcję do Rumunii, czy Turcji („Rząd Francji blokuje inwestycje Renault w Turcji”, Gazeta Wyborcza, 12 stycznia 2010).

${ }^{16}$ Po przejęciu Zakładów Lotniczych „PZL-Mielec” przez korporację Sikorsky, w fabryce uruchomiono zmodernizowaną eksportową wersję amerykańskiego śmigłowca Black Hawka. Śmigłowiec ten jest wykorzystywany w ponad 20 krajach, a głównym odbiorcą są Stany Zjednoczone, a także siły zbrojne Brazylii, Chin, Japonii i Korei Południowej. 
dukcję podzespołów. Ich działalność rozwija się głównie w wyniku wcześniejszych przejęć w ramach prywatyzacji, ulg finansowych prowadzenia działalności gospodarczej oraz wykorzystania relatywnie tańszych wykwalifikowanych zasobów pracy ${ }^{17}$. Przedsiębiorstwa te wykorzystują zazwyczaj miejscową infrastrukturę, istniejący wcześniej park maszynowy lub instalują nowe maszyny i urządzenia sprowadzane z zagranicy. Zakup nowych maszyn wiąże się z przekazywaną dokumentacją technologiczną montażu czy wytwarzania danego produktu, surowców i półfabrykatów, a także z dostarczaniem podzespołów wymagających bardziej zaawansowanych procesów produkcyjnych.

W tej sytuacji oddziały te nie wykazują tendencji do poszukiwania własnych nowych rozwiązań innowacyjnych oferowanych przez krajowe ośrodki akademickie i badawczo-rozwojowe. Dlatego oddziały te, powiązane funkcjonalnie z zagranicznymi zarządami, z reguły nie mają możliwości i potrzeby przedkładania zleceń na wykonanie prac badawczych krajowym ośrodkom akademickim i naukowo-badawczym, stąd w małym stopniu wpływają na pobudzanie rozwoju krajowej myśli naukowej. Wraz z prywatyzacją i przejmowaniem przedsiębiorstw przez koncerny zagraniczne, upadły ośrodki badawczo-rozwojowe funkcjonujące wcześniej w strukturze większych przedsiębiorstw, które uprzednio umożliwiały podejmowanie nowoczesnych produktów ${ }^{18}$. Funkcje ich przejęły ośrodki zagraniczne związane z zarządami korporacji światowych.

Współcześnie w warunkach krajowych, głównym źródłem finansowania w zakresie rozwoju badań podstawowych i prac naukowo-badawczych dającym podstawę kształtowania innowacyjnej gospodarki pozostaje budżet państwa. Działania te realizowane są najczęściej poprzez systemy grantów, dzięki którym finansowane są prace różnych zespołów badawczych. Z reguły w wyniku braku środków na ich wdrożenie do produkcji często osiągnięte rezultaty badawcze przejmowane są przez firmy zagraniczne ${ }^{19}$. Wynika to głównie $\mathrm{z}$ braku właściwej koordynacji w zakresie wdrażania osiągnięć prac naukowo-badawczych do produkcji i praktyki gospodarczej.

W obecnej sytuacji bez znaczniejszego finansowania innowacji poprzez stworzenie kapitału wysokiego ryzyka i przy braku odpowiednich instrumentów prawnych, bardzo trudnym zadaniem jest zmiana relacji między nauką a przedsiębiorcami w zakresie zachęcania ich do korzystania z krajowych osiągnięć naukowo-badawczych. Obecnie ważną rolę w rozwoju innowacyjnych badań a następnie ich wdrażaniu do produkcji i gospodarki powinno odgrywać państwo. Winno ono stwarzać warunki sprzyjające innowacyjnym rozwiązaniom

${ }^{17}$ Wskazuje na to roczna wartość zarobków w krajach Unii Europejskiej, która wynosi w Norwegii od 28,6 tys. euro, Austrii 25,7 tys., Niemczech 24,9 tys., Wielkiej Brytanii 20,7 tys. w Polsce 5,4 tys. a w Rumunii 3,2 tys. i Bułgarii 2,2 tys. (M. Bojanowski, M. Bednarek, „Praca u podstaw”, Gazeta Wyborcza, 8 sierpnia 2011). W Chinach całkowity koszt wytworzenia lalki sprzedawanej w Polsce za 50 zł wynosi 1,7 zł (K. Katka, ,To nie jest zabawne", Gazeta Wyborcza, 7 grudnia 2011).

${ }^{18}$ Przykładem tego może być ośrodek badawczo-rozwojowy działający w strukturze byłej Wytwórni Sprzętu Komunikacyjnego „WSK-Mielec”, w którym skonstruowany został samolot szkolno-treningowy „Iskra” (TS-11), przez zespół pod kierunkiem T. Sołdyka. Samolot był produkowany przez przedsiębiorstwo w latach 1960-1988, a jego wskaźniki techniczne nawiązywały do światowych standardów i długo utrzymywały swoją znaczącą pozycję na rynkach zagranicznych.

${ }^{19}$ Prace nad wykorzystaniem grafenu w elektronice stały się możliwe m.in. dzięki pracy polskich badaczy z Instytutu Technologii Materiałów Elektronicznych oraz Wydziału Fizyki UW. Opracowali oni sposób produkcji grafemu najwyższej jakości na skalę przemysłową, co pozwoliło naukowcom na całym świecie na prowadzenie dalszych badań podstawowych i zastosowań praktycznych na dużą skalę (K. Urbański, „Grafen następcą krzemu”, Rzeczpospolita, 3 lutego 2012). 
oraz finansować je, ponieważ nie stać na to krajowych przedsiębiorstw ani władz samorządowych, a następnie wykorzystywać efekty ekonomiczne wynikające z wdrażania do produkcji nowoczesnych rozwiązań technologicznych, technicznych czy organizacyjnych. W tym zakresie niezbędne są jednostki specjalizujące się nie w administrowaniu (np. tylko podziale środków na cele naukowo-badawcze) ale komercjalizacji wyników prac naukowych i naukowo-badawczych, ponieważ tego zadania w obecnych warunkach nie są w stanie przejąć instytucje naukowe ani rozwijające się nowe przedsiębiorstwa.

Intensyfikacja procesów innowacyjnych poprzez wykorzystanie krajowych ośrodków akademickich i badawczo-rozwojowych może dokonywać się w drodze zacieśniania współpracy z przedsiębiorstwami mającymi siedziby swoich zarządów głównie na terenie kraju. Ośrodki naukowe mogą dostarczać teoretycznych rozwiązań i wypracowywać koncepcje nowych produktów, mogą także częściowo przebadać je we własnych laboratoriach ale przedsiębiorstwa muszą się podjąć ich produkcji w skali półtechnicznej a następnie produkcji masowej. Pomocne w tym zakresie powinny być określone środki finansowe związane z kapitałem wysokiego ryzyka. W obecnej sytuacji wiele nowych koncepcji teoretycznych, częściowo przebadanych i zweryfikowanych w pracach laboratoryjnych, a nawet wdrożonych na małą skalę do produkcji, nie ma możliwości pełnego wdrożenia do produkcji masowej. Główną barierą w tym zakresie jest brak zainteresowania zarządów przedsiębiorstw i obawa podjęcia produkcji w skali półtechnicznej a następne w skali masowej, niespójna krajowa polityka naukowo-badawcza i polityka przemysłowa, jakość elit oraz brak kapitału wysokiego ryzyka ${ }^{20}$. Dlatego ważnym problemem jest stworzenie formalnych możliwości współpracy między krajowymi przedsiębiorstwami, nauką i administracją, które wspólnie wypracują odpowiednie instrumenty prawne, finansowe oraz zasady wzajemnej współpracy na rzecz kreowania innowacyjnych produktów, gospodarki i innowacyjnego społeczeństwa.

\section{WPŁYW CZYNNIKÓW MILITARNYCH NA INTENSYFIKACJĘ PROCESÓW INNOWACJI}

Znaczący wpływ na przyśpieszenie procesów innowacyjnych odgrywają czynniki związane z obronnością. W podstawowym stopniu wpływa na nie zmieniająca się światowa sytuacja polityczna, która przejawia się w tworzeniu różnych ugrupowań państw na rzecz wzajemnego zapewnienia bezpieczeństwa narodowego. W konsekwencji nasilają się różnego typu relacje konkurencyjne prowadzące do zapewnienia coraz nowocześniejszego sprzętu wojskowego. Umożliwiają to znacznie zwiększane nakłady inwestycyjne na prace badawcze, związane z planami budowania nowej infrastruktury obronnej i podejmowania produkcji nowoczesnego uzbrojenia. W niedalekiej przeszłości konkurowały ze sobą państwa skupione w dwóch przeciwstawnych obozach politycznych związanych z krajami byłej europejskiej

\footnotetext{
${ }^{20}$ Wynalazek L. Łagiewki - energetyczny przetwornik akumulacyjno-rozpraszający pochłaniający energię kinetyczną i przetwarzający ją na energię elektryczną - może znaleźć zastosowanie w przemyśle kolejowym, stoczniowym, górniczym i kosmicznym. W 1995 r. został odrzucony i nie mógł zostać opatentowany w Polsce a w 2002 r. został opatentowany przez Schmitha i od 2008 r. jest stosowany w bolidach. Dopiero dzięki szwedzkiemu Królewskiemu Instytutowi Technologicznemu i Centrum Badań Rozwoju podjęte zostały działania na rzecz unieważnienia tego patentu. Od 2009 r. firma Łagiewski stała się jedynym zagranicznym partnerem programu Vision Zero szwedzkiego Ministerstwa Komunikacji (J. Kałucki, „Wsparcie dla Polaka wynalazcy”, Gazeta Wyborcza, 5 grudnia 2011; A. Włodarski, „Batalia o zderzak Lagiewki”, Rzeczpospolita, 11 listopada 2011).
} 
wspólnoty gospodarczej (EWG) oraz byłymi krajami Demokracji Ludowej będącymi pod auspicjami rządu byłego Związku Radzieckiego. Konkurencja ideologiczna między tymi blokami wzmacniana była konkurencją militarną między związanymi z nimi wojskowymi blokami militarnymi NATO i Układem Warszawskim ${ }^{21}$. Nasilająca się konfrontacja ideologiczna, gospodarcza i militarna wpłynęła na uruchomienie „wyścigu zbrojeń”, w wyniku czego następowało systematyczne zwiększanie środków na modernizację i rozwój kompleksu obronnego poprzez zwiększanie środków na badania w zakresie tworzenia coraz nowocześniejszego potencjału militarnego (Albert 1998).

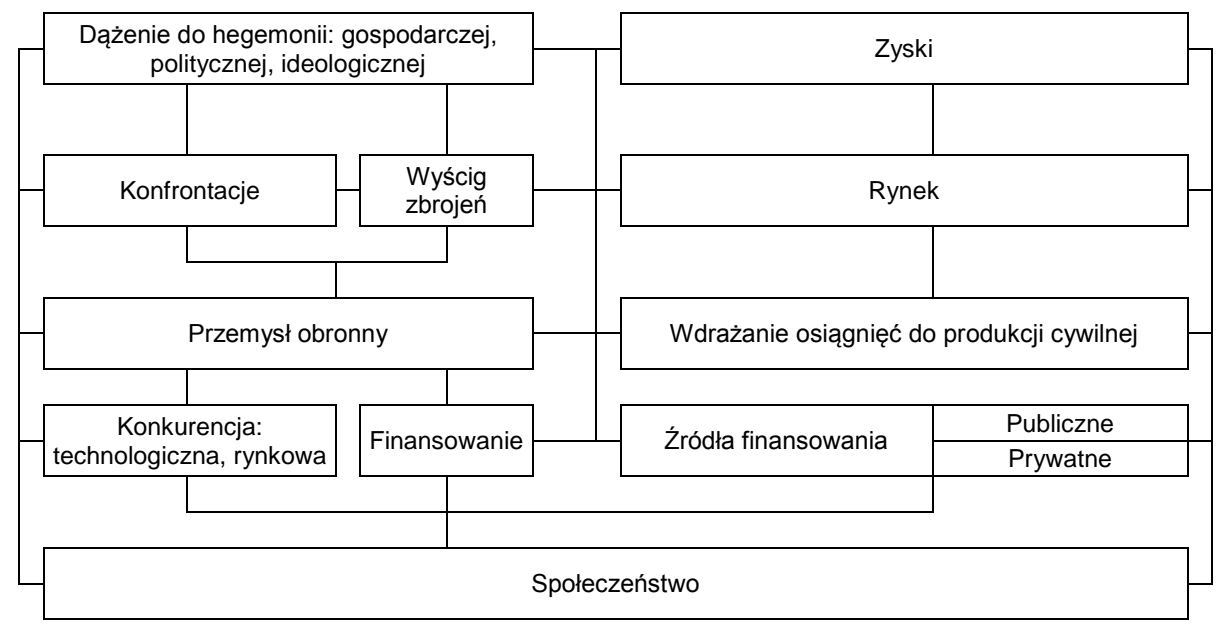

Ryc. 3. Wpływ czynników militarnych na rozwój innowacyjności

Obecnie poważnej zmianie ulega światowa sytuacja polityczna i pojawiają się nowe możliwości konfrontacyjne na polu gospodarczym, politycznym i kultury duchowej, które także mogą stwarzać określone zagrożenia militarne. Pojawiają się nowe kraje podejmujące prace naukowe i konstrukcyjne mające na celu budowę własnej broni nuklearnej (np. Iran), które obecnie poprzez konfrontacje ideologiczne dążą także do konfrontacji politycznej i kulturowej (Koneczny 1935, Huntington 2008). Towarzyszy temu zwiększanie środków przeznaczanych na cele obronności, zwłaszcza w Stanach Zjednoczonych, Chinach, Rosji a także Japonii, Brazylii i Indiach.

Podstawową rolę w tym zakresie odgrywa dążenie do utrzymania hegemonii politycznej, ideologicznej i gospodarczej dominujących krajów, czy grupy państw. Wyzwala to róż-

${ }^{21}$ Kiedy w 1957 r. były Związek Radziecki wysłał w kosmos pierwszego sputnika, Amerykanie powołali Agencję Zaawansowanych Projektów Badawczych (ARPA), której celem były prace nad unowocześnieniem armii amerykańskiej. M.in. przy wsparciu agencji w 1969 r. na Uniwersytecie Kalifornijskim uruchomiono projekt ARPA-NET, którego celem było usprawnienie technik dowodzenia poprzez stworzenie możliwości połączenia komputerów w jedną sieć. Pierwsza sieć obejmowała połączenie czterech różnych uniwersytetów. Badania te służyły dla wypracowania nowoczesnych środków łączności na polu walki. Wyniki badań i ich wykorzystanie w przesyłaniu informacji zaprezentowane zostały publicznie dopiero w $1972 \mathrm{r}$. W oparciu o te badania pierwsza strona internetowa dla celów cywilnych uruchomiona została dopiero w 1990 r. a obecnie obejmuje ona w zasadzie całą przestrzeń światową. 
ne sytuacje konfrontacyjne wyrażające się w prowadzeniu lokalnych wojen, które testują dotychczasowy sprzęt wojskowy oraz wymuszają ciągły rozwój badań, głównie w zakresie nowych materiałów, konstrukcji nowych narzędzi i urządzeń do prowadzenia działań wojennych w różnych uwarunkowaniach potencjalnego pola walki. Realizację tych zamierzeń umożliwia rozbudowywany kompleks przemysłu militarnego, który rozwija się zarówno w wyodrębnionych firmach (najczęściej w utajnionych miejscach lokalizacji) lub w drodze zamówień publicznych w określonych korporacjach przemysłowych. Zamówienia publiczne na środki i sprzęt wojenny są w miarę stałym źródłem dochodu wielu korporacji i stwarzają im dogodne warunki dalszego rozwoju. Dlatego nasilają się między nimi relacje konkurencyjne w zakresie dostarczania najsprawniejszych produktów i urządzeń dających najlepsze efekty na polu działań militarnych. Wyzwala to konkurencję technologiczną i rynkową w zakresie pozyskiwania określonych nakładów finansowych. Ważną rolę w zakresie przeznaczania środków finansowych na cele obronne odgrywa społeczeństwo, które w oparciu o dostarczane informacje decyduje się na przeznaczenie określonych środków budżetowych na cele obronne.

Generalnie przemysł obronny dysponuje dużymi nakładami finansowymi na cele militarne, co pozwala mu na rozwijanie kompleksu badań naukowych nad nowymi materiałami i konstrukcjami, które testowane są w najlepiej wyposażonych laboratoriach naukowych. Dają one podstawę do podejmowania doświadczalnej produkcji sprzętu wojskowego i testowania go w warunkach zbliżonych do pola walki. Rozwijające się badania kompleksu obronnego wprowadzają do produkcji przemysłowej coraz to nowsze materiały i konstrukcje sprzętowe, w wyniku czego znaczna ich część ulega szybkiej dezaktualizacji i stają się nieprzydatne dla obronności kraju. Relatywnie ,przestarzałe materiały, technologie i konstrukcje" nieprzydatne już dla celów obronnych, przekazywane są jako nowoczesne do produkcji cywilnej ${ }^{22}$. Uzyskane z tego tytułu środki stwarzają dodatkowe źródła dochodu kompleksu obronnego i służą do rozwoju dalszych badań nad unowocześnianiem produktów na potrzeby obronności. O roli sektora obronnego w rozwoju innowacyjności świadczą nakłady finansowe z budżetu federalnego Stanów Zjednoczonych na badania i rozwój (tab. 1). W latach 2005-2010 ogólne wydatki rządowe na ten cel zwiększyły się z 126,6 mld dol. do 143,9 mld, tj. do $113,7 \%$, a wśród nich nakłady związane z obronnością wzrosły z 74,0 mld do 86,1 mld, tj. do 116,4\% natomiast ich udział w ogólnych wydatkach zwiększył się odpowiednio z $58,5 \%$ do $59,8 \%$.

${ }^{22}$ Pierwsze komputery służyły do obliczania trajektorii pocisków a Internet wykorzystywany był jako narzędzie wspomagające ośrodki dowodzenia na polu walki a także określania możliwości dyslokacji przestrzennej potencjału obronnego w przypadku ataku nuklearnego. Tworzenie i rozmieszczenie w przestrzeni kilku centrów dowodzenia, koncentracji sił i środków militarnych, produkcji czy remontów uniemożliwia zniszczenie ich przez jeden atak bomby atomowej. Stąd m.in. w latach sześćdziesiątych powstała także teoria równomiernego rozmieszczenia sił wytwórczych, obejmująca głównie lokalizację zakładów przemysłowych, które powinny być rozproszone w przestrzeni krajowej, czy przestrzeni bloków militarnych. Obecnie znaczne środki finansowe przeznaczane są na opracowanie teoretycznych podstaw i możliwości aplikacyjne tzw. sztucznej inteligencji. Wyniki badań wykorzystuje się już do konstrukcji bezzałogowych samolotów (drony), przeznaczonych na cele rozpoznawcze i przenoszenia ładunków wybuchowych, czy robotów mających zastosowanie na polu walki do wykrywania ładunków wybuchowych, czy transportu sprzętu. 
Tab. 1. Wydatki Stanów Zjednoczonych z budżetu federalnego na badania i rozwój

\begin{tabular}{|c|c|c|c|}
\hline \multirow{2}{*}{ Lata } & \multicolumn{3}{|c|}{ Wydatki na badania i rozwój } \\
\cline { 2 - 4 } & Ogółem & $\begin{array}{c}\text { W tym związane } \\
\text { z obronnością }\end{array}$ & $\begin{array}{c}\text { Udział nakładów } \\
\text { na obronność }\end{array}$ \\
\hline 2005 & 126,6 & 74,0 & 58,5 \\
\hline 2006 & 131,6 & 78,0 & 59,3 \\
\hline 2007 & 138,1 & 82,3 & 59,6 \\
\hline 2008 & 140,1 & 84,7 & 60,5 \\
\hline 2009 & 140,9 & 84,9 & 60,3 \\
\hline 2010 & 143,9 & 86,1 & 59,8 \\
\hline 2011 & 143,4 & 82,0 & 57,2 \\
\hline
\end{tabular}

Źródło: National Science Foundation, za J. Przybylski, „Amerykanie chcą być najlepsi”, Rzeczpospolita, 7 listopada 2011. Rok 2010 - dane wstępne, 2011 - projekt

W 2011 r. w Polsce na zakupy nowego uzbrojenia przeznaczono 3,7 mld zł, z czego na jego modernizację wydano 0,7 mld, na zakup części zamiennych 0,3 mld, a na badania i rozwój tylko $0,3 \mathrm{mld}$, podczas gdy na dofinansowanie programów NATO i UE 0,5 mld. Na tym tle można wnosić, że Polska przykłada zbyt mało uwagi do rozwoju krajowej myśli technicznej a bazuje raczej na cudzych osiągnięciach, pomimo, że dotychczasowe wyniki prac konstrukcyjnych pozwalają na podniesienie krajowej pozycji w zakresie produkcji nowoczesnego uzbrojenia. Wyrazem tego może być niewielkich rozmiarów nowoczesna produkcja podejmowana w krajowych przedsiębiorstwach, m.in. bezzałogowych samolotów szpiegowskich, radarów Odra, modułowych karabinków MSBS, kamer obserwacyjnych fusion, artyleryjskich krabów a także cyfrowych systemów rozpoznania, kierowania ogniem i wspomagania dowodzenia ${ }^{23}$.

Podstawowe znaczenie w nowoczesnej produkcji służącej celom obronnym mają osiągnięcia badawcze na polu informatyki, które służą do opracowywania programów sterowania urządzeniami militarnymi. Obok tego rozwijane są prace mające na celu możliwości zakłócania pracy urządzeń bojowych i sprzętu przeciwnika. Odnosi się to np. do zakłócania w zakresie systemów dowodzenia i łączności, czy przejmowania sterowania urządzeniami i sprzętem wojskowym, np. rakietami czy bezzałogowymi samolotami. Badania te mają na celu opracowanie możliwości dokonywania zmian działań zaprogramowanego wcześniej sprzętu bojowego (rakiet, samolotów bezzałogowych, robotów) a ostatnio także możliwości skierowania go z powrotem i niszczenia baz z których wcześniej został wysłany ${ }^{24}$.

${ }^{23}$ Z. Lentowicz, „Gwiazdy arsenałów. Zbrojeniówka goni świat”, Rzeczpospolita, 16 września 2010.

${ }^{24}$ Ostatnio coraz częściej słyszymy o działaniach hakerów blokujących działalność nie tylko instytucji bankowych i rządowych, ale też destabilizujących łączność systemów krajowych. Złośliwy kod odkryli także żołnierze sił powietrznych w Newadzie w swoich komputerach, które służą do sterowania zadaniami bojowymi samolotów bezzałogowych. 
Nie bez znaczenia są tu także możliwości opanowania światowych rynków uzbrojenia oraz osiągane z tego tytułu korzyści ekonomiczne i militarne ${ }^{25}$. Należy zaznaczyć, że eksport broni nie obejmuje najnowszej produkcji a tylko będącą już w powszechnym użytku. Wspomaga to bezpłatna pomoc wojskowa obejmująca najczęściej dostawy do danego kraju wycofywanego już sprzętu wojskowego i uzbrojenia. Wpływa to na zacieśnianie więzi ekonomicznych poprzez konieczność dalszego zaopatrywania się w części zamienne, prowadzenie remontów czy niezbędnych prac modernizacji sprzętu ${ }^{26}$.

\section{KLIMAT SPOŁECZNY DLA ROZWOJU INNOWACYJNOŚCI}

Czynnikiem ograniczającym w naszym kraju rozwijanie nowoczesnej gospodarki jest słaby klimat społeczny stwarzany wokół przedsiębiorców i innowatorów. W stosunku do nich obserwuje się niezbyt przyjazny stosunek administracji, funkcjonuje mało stabilne prawo, słaba przychylność polityków oraz niewłaściwy stosunek społeczeństwa do biznesu. Przedsiębiorcy są zwykle niedoceniani a w tej sytuacji trudno jest myśleć o wychowaniu młodzieży o cechach innowacyjnych i w kulturze poszanowania biznesu. Brak społecznego poparcia $\mathrm{w}$ zakresie rozwoju biznesu jest jedną z podstawowych barier podnoszenia jakości i poziomu życia. Tymczasem w gospodarce występuje konieczność wcześniejszego wytworzenia przez przedsiębiorców odpowiednich produktów, a następnie kierowania ich na rynek, wypracowania odpowiednich przychodów, by po ich opodatkowaniu zasilić budżet, którego rozmiary umożliwią realizację ekonomicznych i społecznych potrzeb ludności. Dlatego konieczna jest zmiana postawy społecznej w stosunku do przedsiębiorców oraz rozwijanie postawy przedsiębiorczej $\mathrm{w}$ procesie dokształcania i doskonalenia zawodowego a także w procesie edukacyjnym wśród dzieci i młodzieży.

Należy podkreślać, że kluczem do sukcesu jest edukacja, która obejmuje dobrze przemyślane i zorganizowane kształcenie oraz zaufanie do ludzkiej przedsiębiorczości. Innowacyjność przedsiębiorców i społeczeństwa wynika bowiem głównie z ich stanu umysłów, na które składają się określone zasoby intelektualne, wiedza i umiejętność posługiwa-

${ }^{25}$ W 2011 r. wartość sprzedanej broni przez Stany Zjednoczone wynosiła 34,8 mld dol. a wartość zawartych umów przemysłu rosyjskiego $36 \mathrm{mld}$ dol. Istnieje w tym zakresie podział terytorialny. Głównymi odbiorcami uzbrojenia amerykańskiego są: Afganistan, Tajwan, Korea Południowa, Australia, kraje arabskie, a uzbrojenia rosyjskiego: Indie, Chiny, Algieria, Wenezuela. W latach 2006-2010 głównymi eksporterami broni na świecie były Stany Zjednoczone, które obejmowały 30\% rynku światowego, Rosja 23\%, Niemcy 11\%, Francja 7\% i Wielka Brytania 4\% (SIPRI, Sztokholm, za I. Rusewicz, „Więcej zamówień dla firm zbrojeniowych”, Rzeczpospolita, 8 grudnia 2011).

${ }^{26}$ Od 1960 r. rząd amerykański realizuje pomoc w ramach programu Foreign Military Financing, który pozwala Kongresowi przydzielać pieniądze sojusznikom i pozwala za te pieniądze kupować sprzęt od firm amerykańskich. W założeniu tego programu przyjęto, że ma on służyć kreowaniu polityki obronnej Stanów Zjednoczonych, poprzez zawieranie sojuszy oraz ma na celu uzależnienie partnerów wieloletnimi umowami poprzez późniejszą eksploatację, serwis i wymuszone zakupy części zamiennych. Za jeden zestaw samolotu bezzałogowego amerykanie żądali od Polski ponad $40 \mathrm{mln}$ zł, czyli ponad połowę więcej niż kwota za którą przekazują go dla własnej armii. Koszty programu zakupu samolotów transportowych „Herkules” zakładano na 75 mln dol., obecnie program pochłonął $135 \mathrm{mln}$ dol. Cena wzrosła bo pierwszy samolot był w kiepskim stanie technicznym - wiele samolotów przejętych później również miało sporo usterek (J. Ćwieluch, „Broń po Wuju”, Polityka, 16 października 2010, s. 36-38). 
nia się nimi. Zakup nowoczesnych technologii nie tworzy jeszcze gospodarki innowacyjnej. Wykorzystywanie i wdrażanie do procesów rozwojowych wzorców z krajów ekonomicznie rozwiniętych daje pozytywne rezultaty tylko wówczas, jeżeli wykształcimy ludzi, którzy potrafią je dostosować do istniejących warunków oraz racjonalnie wykorzystać zgodnie z regułami efektywności ekonomicznej.

\section{NAKŁADY NA DZIAŁALNOŚĆ NAUKOWO-BADAWCZA}

Procesy innowacyjności gospodarki bardzo ściśle związane są z nakładami finansowymi przeznaczanymi na działalność naukowo-badawczą (tab. 2). W skali światowej dominujące znaczenie pod tym względem mają Stany Zjednoczone, które w 2009 r. na ten cel przeznaczyły 398,2 mld dol., tj. 34,8\% ogólnych nakładów analizowanych państw. Drugą pozycję zajmują Chiny (154,1 mld) a trzecią Japonia (137,9 mld dol.) Łącznie te trzy kraje przeznaczyły na działalność naukowo-badawczą 60,3\% ogólnych nakładów finansowych. Kolejne pozycje zajmują: Niemcy (7,2\%), Francja (4,2\%), Republika Korei Południowej, Wielka Brytania i Rosja, które na ten cel łącznie przeznaczyły 21,7\% środków. Wymienione kraje odgrywają podstawową rolę w wielkości nakładów na badania i rozwój i obejmują razem $82,0 \%$ ogólnych nakładów. Znacznie mniejszą rolę odgrywają pozostałe kraje, w tym Polska, która na ten cel wydała 4,9 mld dol., tj. 0,4\% nakładów ogólnych.

Dbałość poszczególnych krajów o innowacyjną gospodarkę ilustruje relacja nakładów przeznaczanych na działalność naukowo-badawczą w odniesieniu do wartości PKB. Dominującą pozycję pod tym względem zajmuje Finlandia, która w stosunku do wartości PKB, na działalność naukowo-badawczą przeznacza 3,96\% nakładów, a następnie Szwecja (3,62\%), Republika Korei Południowej (3,36\%), Japonia (3,33\%), Dania (3,02\%) i Szwajcaria (3,00\%). Następne pozycje zajmują: Stany Zjednoczone, Niemcy, Austria, Francja i Australia. Natomiast najniższym udziałem odznaczają się: Meksyk $(0,37 \%)$, Rumunia (0,47\%), Słowacja (0,49\%) i Argentyna (0,51\%). Polska pod tym względem zajmuje 30 pozycję i na ten cel przeznacza $0,68 \%$ PKB.

Różny jest stopień zainteresowania społecznego finansowaniem działalności naukowo-badawczej. Ilustruje to wskaźnik nakładów na działalność naukowo-badawczą w przeliczeniu na mieszkańca, który wśród analizowanych krajów waha się od 54 dol. do 1425 dol. Dominujące znaczenie pod tym względem mają: Luksemburg (1425 dol.), Finlandia (1397 dol.), Szwajcaria (1363 dol.), Szwecja (1344 dol.) i Stany Zjednoczone (1306 dol.). Kolejne pozycje zajmują: Japonia, Dania, Austria, Niemcy i Norwegia. Najniższymi wartościami wskaźników odznaczają się: Meksyk (54 dol.), Argentyna i Rumunia. Polska zajmuje pod tym względem 29 pozycję o wartości wskaźnika 128 dol. na mieszkańca.

Stopień zaangażowania potencjału demograficznego w pracach naukowo-badawczych obrazuje liczba pracowników naukowo-badawczych w przeliczeniu na 1000 mieszkańców. Dominującą rolą w tym zakresie odznacza się Finlandia $(16,6)$, Dania $(12,3)$ oraz Nowa Zelandia, Japonia, Norwegia, Republika Korei Południowej (dla których wartość wskaźnika waha się od 10,0 do 10,5). W Polsce liczba pracowników zatrudnionych w działalności naukowo-badawczej jest stosunkowo niska i wynosi 3,9, a najniższa jest dla Meksyku $(0,9)$, Republiki Południowej Afryki $(1,4)$ i Chin $(1,5)$. 
Tab. 2. Nakłady i zatrudnienie w działalności naukowo-badawczej w 2009 r.

\begin{tabular}{|c|c|c|c|c|c|c|c|}
\hline \multirow[b]{2}{*}{ Kraje } & \multicolumn{4}{|c|}{ Nakłady } & \multicolumn{2}{|c|}{ Zatrudnienie } & \multirow[b]{2}{*}{$\begin{array}{c}\text { Nakłady } \\
\text { na } 1 \text { pra- } \\
\text { cownika } \\
\text { w tys. dol. }\end{array}$} \\
\hline & $\begin{array}{l}\text { Ogółem } \\
\text { w mln } \\
\text { dol. USA }\end{array}$ & Udział & $\begin{array}{c}\text { Relacja } \\
\text { do PKB } \\
\text { w procen- } \\
\text { tach }\end{array}$ & $\begin{array}{c}\text { Na miesz- } \\
\text { kańca } \\
\text { w dol. } \\
\text { USA }\end{array}$ & Ogółem & $\begin{array}{l}\text { w tym pracow- } \\
\text { nicy naukowo- } \\
\text {-badawczy na } \\
1000 \text { pracują- } \\
\text { cych }\end{array}$ & \\
\hline Razem & 1145189 & 100,0 & . & . & . & . & . \\
\hline $\begin{array}{l}\text { Stany } \\
\text { Zjednocz. }\end{array}$ & 398194 & 34,8 & 2,79 & 1306 & . & 9,5 & . \\
\hline Chiny & 154147 & 13,5 & 1,70 & 115 & 2291252 & 1,5 & 67,3 \\
\hline Japonia & 137909 & 12,0 & 3,33 & 1183 & 878418 & 10,4 & 157,0 \\
\hline Niemcy & 82731 & 7,2 & 2,78 & 1011 & 529526 & 7,7 & 156,2 \\
\hline Francja & 47954 & 4,2 & 2,21 & 744 & 384513 & 8,9 & 124,7 \\
\hline $\begin{array}{l}\text { Republika } \\
\text { Korei Połud. }\end{array}$ & 43906 & 3,8 & 3,36 & 903 & 294440 & 10,0 & 149,1 \\
\hline $\begin{array}{l}\text { Wielka } \\
\text { Brytania }\end{array}$ & 40280 & 3,5 & 1,85 & 652 & 347486 & 8,3 & 115,9 \\
\hline Rosja & 33368 & 2,9 & 1,24 & 235 & 845942 & 6,4 & 39,4 \\
\hline Włochy & 24753 & 2,2 & 1,27 & 411 & 239246 & 4,1 & 103,5 \\
\hline Kanada & 24551 & 2,1 & 1,92 & 728 & 242686 & 8,6 & 101,2 \\
\hline Hiszpania & 20496 & 1,8 & 1,38 & 446 & 220777 & 7,0 & 92,8 \\
\hline Australia & 18755 & 1,6 & 2,21 & 867 & 136696 & 8,4 & 137,2 \\
\hline Szwecja & 12495 & 1,1 & 3,62 & 1344 & 75847 & 10,5 & 164,7 \\
\hline Niderlandy & 12274 & 1,1 & 1,82 & 743 & 87874 & 6,4 & 139,7 \\
\hline Szwajcaria & 10519 & 0,9 & 3,00 & 1363 & 62066 & 5,6 & 169,5 \\
\hline Austria & 8931 & 0,8 & 2,75 & 1068 & 58002 & 8,5 & 154,0 \\
\hline Turcja & 8681 & 0,8 & 0,85 & 121 & 73521 & 2,7 & 118,1 \\
\hline Belgia & 7685 & 0,7 & 1,96 & 712 & 60005 & 8,4 & 128,1 \\
\hline Finlandia & 7458 & 0,7 & 3,96 & 1397 & 56069 & 16,6 & 133,0 \\
\hline Dania & 6284 & 0,5 & 3,02 & 1138 & 57507 & 12,3 & 109,3 \\
\hline Meksyk & 5720 & 0,5 & 0,37 & 54 & 70293 & 0,9 & 81,4 \\
\hline Polska & 4879 & 0,4 & 0,68 & 128 & 73581 & 3,9 & 66,3 \\
\hline Norwegia & 4734 & 0,4 & 1,76 & 981 & 36091 & 10,1 & 131,2 \\
\hline $\begin{array}{l}\text { Rep. Połud. } \\
\text { Afryki }\end{array}$ & 4689 & 0,4 & 0,93 & 94 & 30802 & 1,4 & 152,2 \\
\hline Portugalia & 4411 & 0,4 & 1,66 & 415 & 52313 & 9,1 & 84,3 \\
\hline $\begin{array}{l}\text { Republika } \\
\text { Czeska }\end{array}$ & 4095 & 0,4 & 1,53 & 390 & 50961 & 5,5 & 80,4 \\
\hline Irlandia & 3165 & 0,3 & 1,79 & 708 & 20786 & 7,7 & 152,3 \\
\hline Argentyna & 2679 & 0,2 & 0,51 & 68 & 53187 & 2,9 & 50,4 \\
\hline
\end{tabular}




\begin{tabular}{|l|l|l|l|l|l|l|l|}
\hline Węgry & 2334 & 0,2 & 1,15 & 233 & 29795 & 5,0 & 78,3 \\
\hline Grecja & 1868 & 0,2 & 0,59 & 167 & 35629 & 4,4 & 52,4 \\
\hline Rumunia & 1472 & 0,1 & 0,47 & 69 & 28398 & 2,1 & 51,8 \\
\hline $\begin{array}{l}\text { Nowa } \\
\text { Zelandia }\end{array}$ & 1423 & 0,1 & 1,17 & 335 & 24700 & 10,8 & 57,6 \\
\hline Słowenia & 1044 & 0,1 & 1,86 & 511 & 12410 & 7,7 & 84,1 \\
\hline Luksemburg & 709 & 0,1 & 1,68 & 1425 & 4689 & 6,8 & 151,2 \\
\hline Słowacja & 596 & 0,1 & 0,48 & 110 & 15952 & 6,1 & 37,4 \\
\hline
\end{tabular}

Źródło: GUS, Rocznik Statystyczny 2011, s. 801

W zakresie potencjalnych efektów działalności naukowo-badawczej duże znaczenie mają nakłady na działalność badawczo-rozwojową w przeliczeniu na jednego zatrudnionego, co wyraża m.in. poziom uzbrojenia pracy. Wartość tego wskaźnika charakteryzuje się dużym zróżnicowaniem, którego wartość waha się od 37 tys. dol. do 169,5 tys. dol. Dominującą rolę pod tym względem zajmują: Szwajcaria (169,5 tys. dol.), Szwecja (164,7 tys.), Japonia, Niemcy, Austria, Irlandia, Republika Południowej Afryki i Luksemburg. Najniższymi nakładami charakteryzują się Słowacja (37,4 tys.) i Rosja (39,4 tys.). Polska pod tym względem zajmuje 28 pozycję, przeznaczając na jednego pracownika działalności naukowo-badawczej 66,3 tys. dol.

Przedstawione rozważania wskazują, że Polska zajmuje zazwyczaj końcowe pozycje pod względem wskaźników finansowania działalności naukowo-badawczej. W tej sytuacji pojawiające się często negatywne opinie o poziomie i jakości prowadzonych w Polsce badań naukowych, wyrażane niekiedy przez prominentne w państwie osoby, wydają się nieuzasadnione i świadczą o braku przez nie znajomości realiów z jakimi boryka się polska nauka. W takiej sytuacji trudno liczyć na zwiększenie liczby patentów, które wynikają nie tylko w braku środków na ewentualne zgłoszenia, ale także z biurokratycznych barier zniechęcających niekiedy polskich twórców. Nic więc dziwnego, że wiele polskich pomysłów wędruje za granicę a nie zostaje zrealizowanych w kraju.

\section{Miejsce Polski w strukturze Rangowej innOwacyjności}

Wśród 110 krajów ocenianych przez Boston Consulting Group w zakresie badań naukowych i innowacyjnych Polska zajęła 52 pozycję, przy czym pod względem liczby publikacji naukowych zajmujemy w świecie 19 pozycję. Natomiast słabością są braki w zakresie wdrażania osiągnięć do gospodarki (Stanisławska 2011). Należy zaznaczyć, że wdrażanie osiągnięć do gospodarki wynika, jak już wspomniano, z braku odpowiedniej polityki innowacyjnej państwa, która przejawia się w luce między osiągnięciami naukowo-badawczymi a możliwościami ich wdrożenia do praktyki gospodarczej a także braku umiejętności a często chęci nawiązania wzajemnego kontaktu między przedstawicielami nauki i praktyki gospodarczej, zwłaszcza ze strony administracji państwowej, która nie zawsze jest odpowiednio przygotowana do wykorzystania dorobku naukowo-badawczego ${ }^{27}$.

${ }^{27} \mathrm{~W}$ konsekwencji np. wiele prac dyplomowych, które mają duże wartości aplikacyjne, pozostaje w archiwach, głównie ze względu na brak zainteresowania ze strony władz samorządowych. Wynika to częściowo z braku 
W klasyfikacji przeprowadzonej przez Summary Innovation Index, wśród krajów Unii Europejskiej Polska znalazła się na 23 miejscu. Pierwszą pozycję zajmuje Szwajcaria, która osiągnęła 0,83 pkt, a następnie Szwecja (0,75), Dania (0,75), Niemcy i Finlandia (po 0,70). Polska $(0,28)$ znalazła się za Węgrami $(0,33)$ i przed Słowacją $(0,27)$. Ranking zamykają Litwa i Bułgaria (po 0,23). W latach 2006-2010 najwyższym wzrostem charakteryzowały się Bułgaria (6,15\%), Rumunia (5,23\%), Francja (2,74\%) i Finlandia (2,72\%), a dynamika Polski wynosiła $1,79 \%$.

Ważnym czynnikiem innowacyjności gospodarki są uwarunkowania w zakresie swobody gospodarczej, które stwarzają instrumenty prawne nawiązujące do przyjętych zasad polityki gospodarczej. Wśród 184 krajów Polska pod tym względem znalazła się na 64 miejscu, natomiast w czołówce znalazły się Hongkong, Singapur, Australia i Nowa Zelandia. Stany Zjednoczone zajęły 10 pozycję, a Grecja $119^{28}$.

Zakładanie przez Ministerstwo Gospodarki, że w 2020 r. Polska znajdzie się w grupie krajów mocno innowacyjnych wydaje się mało realne, ponieważ należało by się wspiąć do góry o 15 pozycji. Nakłady na badania i rozwój musiałyby się zwiększyć do 1,7\% PKB, czyli dojść do poziomu jakim charakteryzują się Wielka Brytania, Holandia, Słowenia, które przeznaczają na ten cel od $1,77 \%$ do $1,66 \% \mathrm{w}$ stosunku do PKB. Wymagałoby to także usunięcia wspomnianych barier w zakresie zintegrowania procesu badawczego z aplikacją osiągniętych wyników przez praktykę gospodarczą.

\section{UwAGI KOŃCOWE}

Procesy innowacyjne w przedsiębiorstwie, gospodarce, życiu społecznym i kulturze przejawiają się w umiejętności kreowania nowych idei i koncepcji rozwojowych, które umożliwiają prowadzenie prac naukowo-badawczych, pozwalających na wdrażanie do produkcji i działalności usługowej nowych technologii, organizacji oraz nowych form zarządzania nimi w oparciu o efektywność ekonomiczną.

Podstawowym czynnikiem pobudzającym rozwój innowacyjności jest odpowiednio wyedukowany człowiek o cechach przedsiębiorczych, który ciągle poszukuje nowych rozwiązań w zakresie wytwarzania nowych i doskonalenia już istniejących coraz bardziej kon-

możliwości podejmowania samodzielnych decyzji w zakresie zmian istniejących systemów zarządzania, które zakłócają dotychczasowe metody sprawowania władzy.

${ }^{28}$ Sytuację w kraju ilustruje w nieco kabaretowym stylu W. Grzegorczyk „Nie łudźmy się, jeszcze długo nie będziemy ważnym graczem w światowej stawce innowacji. Na innowację stać bogate i kraje i firmy. A całe gadanie naszych polityków, lobbystów i tzw. działaczy gospodarczych o tym, jaką ważną szansą dla polskiej gospodarki są badania i rozwój, nie mają wielkiego sensu. Aż strach pomyśleć, co by się stało, gdyby np. nasz rząd na poważnie zajął się projektem wspierania innowacji w gospodarce. Zapewne najpierw powstałoby jakieś ministerstwo, a przynajmniej centralny urząd, w którym po długich, koalicyjnych targach, zatrudnienie z wysoką pensją znalazłoby kilka tuzinów polityków, ich krewnych i znajomych. Następnie utworzony zostałby fundusz, lub agencja, hojnie zasilana pieniędzmi z budżetu, albo ze specjalnej daniny nałożonej na firmy, gdzie znowu powstałoby sporo intratnych posad. Ze zgromadzonych pieniędzy agencja dofinansowałaby różnego rodzaju projekty. Co jakiś czas, po kontroli NIK okazałoby się, że badania realizowane przez firmy i instytucje naukowe w jakiś sposób powiązane z politykami partii aktualnie rządzącej, nie przyniosły oczekiwanych rezultatów” („Innowacje - temat nie dla polityków”, Rzeczpospolita, 19 października 2011). 
kurencyjnych produktów, a także przygotowany do wdrażania nowych organizacji produkcji i życia społecznego.

Ważną rolę spełniają także uwarunkowania otoczenia przejawiające się $\mathrm{w}$ dbałości o pozytywny klimat społeczny w stosunku do przedsiębiorców i ich działań innowacyjnych. Szczególne znaczenie ma tu wdrażanie racjonalnych i stabilnych instrumentów bezpośredniego i pośredniego oddziaływania oraz przyjazne instytucje finansowe.

Ważną rolę w procesie kreowania i wdrażania innowacyjnych rozwiązań odgrywają postawy i stopień przygotowania przedstawicieli władzy ustawodawczej, władz państwowych, samorządowych oraz społeczeństwa, które mają wykształconą gotowość i umiejętności stawiania celów, i wdrażania działań innowacyjnych w zmieniających się uwarunkowaniach krajowych, europejskich i światowych.

Szczególnie ważną rolę odgrywa stworzenie warunków do zacieśnienia powiązań między badaniami podstawowymi, pracami naukowo-badawczymi, laboratoryjnymi, produkcją doświadczalną w skali półtechnicznej i produkcją masową, m.in. poprzez tworzenie funduszy podwyższonego ryzyka, mobilizujących kapitał państwowy i prywatny do finansowania projektów innowacyjnych.

Ważną rolę odgrywają działania na rzecz utrzymywania, pogłębiania i rozszerzania rynku dla innowacyjnych produktów i rozwiązań organizacyjnych, obejmujące zarówno poszczególne sektory gospodarki jak i gospodarkę regionalną, krajową, europejską i światową.

Dla realizacji założonych celów podstawową rolę odgrywają zasady organizacyjne w zakresie kształtowania spójnego systemu zarządzania obejmującego podmioty gospodarcze, instytucje i społeczeństwo. Winny one prowadzić do zmian świadomości społecznej i politycznej oraz przyśpieszać proces budowy kapitału społecznego, celem osłabienia bariery wzajemnej nieufności przedsiębiorców, instytucji i społeczeństwa.

\section{Literatura}

Albert M., 1994, Kapitalizm kontra kapitalizm, Sinum, Kraków.

Dobrowolska M. (red.), 1968, Demograficzno-osadnicze problemy w Tarnobrzeskim Rejonie Uprzemysławianym, Zeszyty Badań Rejonów Uprzemysławianych KBRU przy Prezydium PAN, z. 29.

Carnicky S., Krupa K., Skotny P. (red.), 2011, Business Intelligence. Theory and Practice. RzeszówKosice.

Ciok S., Dobrowolska-Kaniewska H., 2009, Polityka innowacyjna państwa a regionalny potencjat innowacyjny, Przykład Dolnego Ślaska. Rozprawy Naukowe Instytutu Geografii i Rozwoju Regionalnego Uniwersytetu Wrocławskiego, Wrocław.

Długosz Z., Zioło Z. (red.), 2010, Rozwój naukowo-dydaktyczny i kierunki badawcze Instytutu Geografii, Wydawnictwo Naukowe Uniwersytetu Pedagogicznego w Krakowie, Kraków.

Heffner K., Kamińska W., 2010, Kapitał ludzki i społeczny w procesie rozwoju obszarów wiejskich, Studia KPZK PAN, t. CXXVI, Warszawa.

Huntington S.P., 1998, Zderzenie cywilizacji, MUZA, Warszawa.

Kukliński A., 2005, Gospodarka oparta na wiedzy, wyzwania dla Polski XXI wieku, Komitet Badań Naukowych, Warszawa.

Klasik A. (red.), 2008, Aktywność przedsiębiorcza i konkurencyjność ekonomiczna w procesie restrukturyzacji aglomeracji miejskich, Wyd. AE, Katowice. 
Klasik A. (red.), 2011, Kreatywne przemysty - kreatywne aglomeracje, Biuletyn KPZK PAN, z. 246.

Koneczny F., 1935, O wielości cywilizacji, Wyd. Gebether Wolff, Kraków. Reprint, Wyd. Antyk, Komorów 1998.

Kukliński A., 1995, Nauka - technologia-gospodarka, Komitet Badań Naukowych, Warszawa.

Kwiatkowski E., 1989, Dysproporcje - Rzecz o Polsce przeszłej i obecnej, Czytelnik, Warszawa.

Rajman J., 1969, Procesy urbanizacyjne w obrzeżu Górnośląskiego Okręgu Przemystowego po II wojnie światowej, Prace Monograficzne, Wydawnictwo Naukowe WSP, Kraków.

Stanisławska A., 2011, Innowacyjność jest dla Polski koniecznościa, Rzeczpospolita, lista 2000, 23 października.

Stryjakiewicz T., Stachowiak K., 2010, Uwarunkowania, poziom i dynamika rozwoju sektora kreatywnego w poznańskim obszarze metropolitalnym, Bogucki Wydawnictwo Naukowe, Poznań.

Stryjakiewicz T., Męczyński M., 2010, Atrakcyjność poznańskiego obszaru metropolitalnego dla pracujacych w sektorze kreatywnym, Bogucki Wydawnictwo Naukowe, Poznań.

Stryjakiewicz T, Kaczmarek T., Męczyński M., Parysek J.J., Stachowiak K., 2010, Polityka wspierania rozwoju sektora kreatywnego w poznańskim obszarze metropolitalnym na tle doświadczeń zagranicznych, Bogucki Wydawnictwo Naukowe, Poznań.

Śleszyński P., 2007, Gospodarcze funkcje kontrolne w przestrzeni Polski, Prace Geograficzne nr 213, Instytut Geografii i Przestrzennego Zagospodarowania PAN, Warszawa.

Śleszyński P., 2007, Gospodarcze funkcje kontrolne w przestrzeni Polski, Instytut Geografii i Przestrzennego Zagospodarowania PAN, Prace Geograficzne nr 213, Warszawa.

Śleszyński P., 2010, Powiąania organizacyjne $i$ właścicielskie przedsiębiorstw przemystowych $i$ ustugowych $w$ Polsce oraz ich znaczenie dla rozwoju regionalnego, [w:] Z. Zioło, T. Rachwał (red.), Procesy transformacji przemystu $i$ ustug $w$ regionalnych $i$ krajowych układach przestrzennych, Prace Komisji Geografii Przemysłu Polskiego Towarzystwa Geograficznego, nr 15, Wyd. Naukowe Uniwersytetu Pedagogicznego im. Komisji Edukacji Narodowej w Krakowie, Warszawa-Kraków, s. 117-129.

Zioło Z. (red.), 1978, Przemiany społeczno-ekonomiczne Tarnobrzeskiego Rejonu Uprzemysławianego, Seria: Problemy Rejonów Uprzemysławianych KBRU, PWN, Warszawa.

Zioło Z., 2009a, Procesy ksztaltowania się światowych korporacji i ich wplyw na otoczenie, [w:] Z. Zioło, T. Rachwał (red.), Wpływ procesów globalizacji i integracji europejskiej na transformacje struktur przemysłowych, Prace Komisji Geografii Przemysłu Polskiego Towarzystwa Geograficznego, nr 12, Wyd. Naukowe Akademii Pedagogicznej im. Komisji Edukacji Narodowej w Krakowie, Warszawa-Kraków, s. 11-31.

Zioło Z., 2009b, Rola przemystu w ksztattowaniu społeczeństwa informacyjnego, [w:] Z. Zioło, T. Rachwał (red.), Funkcje przemystu w ksztaltowaniu społeczeństwa informacyjnego, Prace Komisji Geografii Przemysłu Polskiego Towarzystwa Geograficznego, nr 13, Wyd. Naukowe Uniwersytetu Pedagogicznego im. Komisji Edukacji Narodowej w Krakowie, WarszawaKraków, s. 11-20.

Zioło Z., Rachwał T. (red.), 2008, Problematyka badawcza geografii przemystu, Prace Komisji Geografii Przemysłu Polskiego Towarzystwa Geograficznego, nr 11, Wyd. Naukowe Akademii Pedagogicznej im. Komisji Edukacji Narodowej w Krakowie, Warszawa-Kraków.

Zioło Z., Rachwał T. (red.), 2009a, Wpływ procesów globalizacji i integracji europejskiej na transformacje struktur przemysłowych, Prace Komisji Geografii Przemysłu Polskiego Towarzystwa Geograficznego, nr 12, Wyd. Naukowe Akademii Pedagogicznej im. Komisji Edukacji Narodowej w Krakowie, Warszawa-Kraków.

Zioło Z., Rachwał T. (red.), 2009b, Funkcje przemystu w ksztattowaniu spoteczeństwa informacyjnego, Prace Komisji Geografii Przemysłu Polskiego Towarzystwa Geograficznego, nr 13, Wyd. Naukowe Uniwersytetu Pedagogicznego im. Komisji Edukacji Narodowej w Krakowie, Warszawa-Kraków. 
Zioło Z., Rachwał T. (red.), 2010a, Procesy transformacji przemystu i ustug $w$ regionalnych $i$ krajowych układach przestrzennych, Prace Komisji Geografii Przemysłu Polskiego Towarzystwa Geograficznego, nr 15, Wyd. Naukowe Uniwersytetu Pedagogicznego im. Komisji Edukacji Narodowej w Krakowie, Warszawa-Kraków.

Zioło Z., Rachwał T., 2010b, Procesy przemian przemysłu i usług w wybranych krajach, Prace Komisji Geografii Przemysłu Polskiego Towarzystwa Geograficznego, nr 16, Wyd. Naukowe Uniwersytetu Pedagogicznego im. Komisji Edukacji Narodowej w Krakowie, Warszawa-Kraków.

Zioło Z., Rachwał T. (red.), 2011, Wpływ kryzysu na zachowania przedsiębiorstw oraz przemiany struktur regionalnych, Prace Komisji Geografii Przemysłu Polskiego Towarzystwa Geograficznego, nr 17, Wyd. Naukowe Uniwersytetu Pedagogicznego im. Komisji Edukacji Narodowej w Krakowie, Warszawa-Kraków.

Zioło Z., 2012, Procesy kształtowania innowacyjnego miasta, Studia KPZK PAN (złożone do druku).

\section{Position of innovativeness in the processes of economic development of spatial structures}

The present article concerns the issues of innovativeness in the development of enterprises and in the processes of economic, social and cultural development. The aim of this work is to determine the scope of development of innovation processes, and to present the position of Poland in the ranking list according to the advancement of innovation processes.

Prof. dr hab. Zbigniew Zioło

Uniwersytet Pedagogiczny, Kraków

Instytut Geografii

Zakład Przedsiębiorczości i Gospodarki Przestrzennej

e-mail: ziolo@up.krakow.pl 